\title{
Dreamers and Nightmares
}

Political novels by Wang Lixiong and Chan Koonchung

\section{Chaohua Wang}

\section{OpenEdition}

\section{Journals}

Electronic version

URL: http://journals.openedition.org/chinaperspectives/6636

DOI: $10.4000 /$ chinaperspectives.6636

ISSN: 1996-4617

\section{Publisher}

Centre d'étude français sur la Chine contemporaine

\section{Printed version}

Date of publication: 1 March 2015

Number of pages: 23-31

ISSN: 2070-3449

\section{Electronic reference}

Chaohua Wang, «Dreamers and Nightmares », China Perspectives [Online], 2015/1 | 2015, Online since 01 January 2017, connection on 28 October 2019. URL : http://journals.openedition.org/ chinaperspectives/6636; DOI : 10.4000/chinaperspectives.6636

(C) All rights reserved 


\title{
Dreamers and Nightmares
}

\author{
Political novels by Wang Lixiong and Chan Koonchung
}

\author{
CHAOHUA WANG
}

\begin{abstract}
Wang Lixiong's Yellow Peril (1991) represents the return of political fiction of the future not seen in China for decades. Chan Koonchung's The Fat Years (2009) brings the imagination to a full dystopian vision. Reading the two novels side by side, this paper argues that Chinese fiction of the future in the early 1990s responded to the country's struggle for direction when the bloody crackdown of the Tiananmen protest wiped out collective idealism in society. In the twenty-first century, such fiction is written in response to China's rapid rise as one of the world's superpowers, bringing to domestic society a seemingly stabilised order that has deprived it of intellectual vision.
\end{abstract}

KEYWORDS: Political novel, dystopian literature, Wang Lixiong, Chan Koonchung, Yellow Peril, The Fat Years.

\section{Introduction}

$\mathrm{P}$ olitically, the twentieth century in China has been seen as a century of wars and revolutions, except, perhaps, the last decade. Correspondingly, modern Chinese literature channelling the deep-rooted human desires and anxieties of the century created richly variegated and imaginative works of fiction, of which realism was long regarded as the dominant genre and style by literary historians inside China and abroad. This view has been challenged since scholars endeavoured to break the rigid political barrier demarcating the May Fourth period from its immediately preceding decades. Perry Link is a pioneer in this direction, publishing his study on early twentieth century urban literature in 1981.(1) The studies on modern Chinese narratology by Chen Pingyuan and Henry Y. H. Zhao, Xiaobing Tang's work on Liang Qichao, and David Der-wei Wang's literary excavation of the late Qing splendour all contributed to renewing scholarly interest beyond the discourse of realism. (2) Since then, one work that used to be dismissively regarded but can no longer be ignored by anyone working in the modern Chinese literature field is Liang Qichao's unfinished futuristic novel, Future of New China (Xin Zhongguo weilai ji 新中國未來記, 1902). Its global scope and nationalistic optimism pioneered the signature spirit that infused much of the revolutionary and developmental decades up to the present time. Political, utopian, and science-fictional, the novel is now viewed as a prototype of the non-realistic schools in the modern Chinese narrative tradition.

On the other hand, considering historical context in a global setting, we must admit that Liang's novel belongs specifically to his own age. Before the Great War in Europe in the late 1910s, there was a period of rapid industrialisation stimulated by scientific discoveries, technological innovations, and world-wide competitive expansion of capitalism. This was accompanied by increasing nationalism around the world, and ambitious aspirations fuelled by confidence in humanity's ability to master both nature and human affairs. In the West, a leading representative writer of this conviction is Jules Verne, whose numerous works of science fiction, adventurers' tales, and nationalistic thrillers were permeated with confidence in humanity. An equally imaginative while somewhat sceptical voice was $\mathrm{H}$.
G. Wells, but his critical edge was not perceptively appreciated in China. Fictional works imagining a future reality in the late Qing period are generally set in positive tones and usually with tangible fascination with future scientific potential, as clearly manifested in Liang's novel as well as in, for example, New Year's Dream (Xinnian meng 新年夢, 1904) by Cai Yuanpei, and New Story of the Stone (Xin shitou ji 新石頭記, 1908) by Wu Woyao.

The worldwide trend suffered an abrupt setback in the interwar period of the 1920s and 1930s. Confidence in the ethical value of scientific knowledge and human social design was seriously challenged in works such as the early Soviet writerYevgeny Zamyatin's We (1921) and Aldous Huxley's Brave New World (1932), and in the post-war period by George Orwell's Nineteen Eighty-Four (1949), all regarded as classics in the broadly defined genre of dystopia literature with some science fiction features. In China, Liang Qichao himself became disillusioned with the blind worship of science and nationalism when he visited Europe at the end of the WWI, which led him into the famous debate of "Science versus Metaphysics" in 1923. (3) But by now Liang expressed himself through travelogues and commentaries and was no longer writing novels. In fictional form, it was Lao She's The City of Cats (Mao cheng ji 貓城記, 1932) that satirised fake confidence carrying ubiquitous banners promoting all things "new." The Cat City's final demise in an almost self-inflicted disastrous military confrontation was so dark that the theme was not revisited by mainland Chinese writers until the early 1990s. However, neither Liang's position in the 1920s nor Lao She's The City of Cats was highly regarded by cultural reformers or revolutionary elites for decades to come. Supported by scientific claims, grand utopian visions rejected opposition. This was particularly true when the Communist Party

1. Perry Link, Mandarin Ducks and Butterflies: Popular Fiction in Early Twentieth Century Chinese Cities, Oakland, University of California Press, 1981

2. Chen Pingyuan, Zhongguo xiaoshuo xushi moshi de zhuanbian (Transformation of Chinese Fiction's Narrative Mode), Shanghai, Shanghai renmin chubanshe, 1988; HenryY. H. Zhao, The Uneasy Narrator: Chinese Fiction from the Traditional to the Modern, Oxford University Press, 1995; Xiaobing Tang, Global Space and the Nationalist Discourse of Modernity: The Historical Thinking of Liang Qichao, Stanford, Stanford University Press, 1996; David Der-wei Wang, Fin-de-Siècle Splendor: Repressed Modernities of Late Qing Fiction, 1849-1911, Stanford, Stanford University Press, 1997.

3. Xiaobing Tang, Global Space and the Nationalist Discourse of Modernity, op. cit., pp. 175-220. See Roger B. Jeans Jr., Democracy and Socialism in Republican China:The Politics of Zhang Junmai (Carsun Chang), 1906-1941, Lanham, Roman \& Littlefield Publishers, 1997. 
came to power in 1949, persecuting large numbers of people for straying from its version of Grand Utopia. Henry H.Y. Zhao suggests that the reason realism dominated fiction writing for more than half a century after the late 1910s is most likely because the need to imagine future potential uncertainty was replaced by faith in a future certainty. "The separation between the utopia and the reality had to be scaled with power [or revolutionary forces before seizing power] but not imagination." Half a century later, when the end of the Cultural Revolution signalled the collapse of the official version of Grand Utopia, it was time for utopian fiction to reemerge. (4) Zhao believes that utopian imagination was already widely present in the root-seeking literature of the mid-eighties, but its projected location was usually spatially separated from reality. The fiction of the future of temporal imagination did not appear until the nineties, when "mono-dimensional history" ended in China. ${ }^{(5)}$ However, Zhao does not further explain his observation or pursue his argument in the periodisation. The current study aims to bring out the historical context of political utopian/dystopian fiction in contemporary China through reading two works from the early 1990s and the early twenty-first century.

Wang Lixiong's Yellow Peril (Huanghuo 黃禍) was first published anonymously in Hong Kong in 1991, a mere two years after the crackdown on the Tiananmen protests and half a year before Deng Xiaoping's Southern Tour revived the Chinese economy. Yellow Peril begins with severe power struggles manipulating the redress of the Tiananmen Massacre and weaves China's internal conflicts into a full-fledged nuclear world war. It ends with a bifurcated outcome of the disaster. On the one hand, resource exhaustion has turned human beings into beasts and has completely erased all traces of civilisation inside China's territory. On the other hand, hundreds of millions of destitute refugees, crossing oceans and continents around the world have learned to organise themselves according to the program of bottomup gradational election, which allows them to live collectively in a self-disciplined manner and cooperative spirit so they can survive off the very limited resources the Earth is able to provide. ${ }^{(6)}$

When Chan Koonchung's The Fat Years (literally, Prosperity: China in 2013, Shengshi: Zhongguo 2013 盛世: 中國 2013) was published in 2009, China had hosted the 2008 Beijing Olympics with great fanfare and celebrated the PRC's sixtieth anniversary, a particularly important number in Chinese culture. Imagining an almost universal acceptance of the status quo, the novel follows a few restless souls who are isolated in a sea of happy masses. They eventually join force to uncover the truth of dark political designs. With rich literary references, the novel also allows its characters to ponder philosophical issues, exploring along the way the social and global implications of China's ascendance to superpower status. (7)

I would argue that the re-emergence of political fiction about the future of China, represented by Wang Lixiong's Yellow Peril, responded on the one hand to the country's struggle for direction following the bloody quelling of the Tiananmen protests that wiped out collective idealism of the 1980s. On the other hand, it recognised in its own way the invalidated state of a teleological Grand Narrative that supposedly guided all human societies on Earth. At the closing moment of the Cold War, it was time to reconsider the purpose and organising principles of human society for the good of Mankind as a whole. In the twenty-first century, however, developmental discourse seems to be the footing for most of the noisy exclamations in China and in many other places around the world. Correspondingly, fiction of the future such as The Fat Years responds to a seemingly stabilised order that depresses serious intellectual engagement in crucial issues concerning memories of the past and visions of humanity's collective future. The future is bound to history once again, and old Enlightenment questions concerning emancipation, freedom, and progress have re-emerged, urgently appealing for attention.

Wang Lixiong and Chan Koonchung are not career writers in the conventional sense, or at least in the Chinese context, as neither is a member of the official Chinese Writers' Association (Wang renounced his membership in 2001). In addition to writing fiction, they are both well-known cultural figures and are actively involved in many socio-political issues, such as environmental, ethnic, and regional politics in Tibet, the Uyghurs of Xinjiang, or Hong Kong. Their political novels appear to be in line with their political involvement in general and are not confined to merely literary exercises. In a similar vein, they have both written books of socio-political analyses as publicly concerned intellectuals rather than as specially trained scholars. Yet, as we shall see later, their novels are not mere vehicles for political messages, either.

In comparison, Wang Shuo, the popular novelist, screenwriter, and producer, and Mo Yan, the Nobel laureate in literature (2012), each produced satiric dystopian parables of their own, Wang Shuo's Please Don't Call me Human (Qianwan bie ba wo dang ren 千萬別把我當人, 1989) and Mo Yan's The Republic of Wine (Jiu guo 酒國, 1992). ${ }^{(8)}$ These satires take a local perspective to expose the depth of social disintegration and pervasive decay, a society corrupted under the pressure of wholesale economic marketisation with little or no moral restraints. These two novels experienced some temporary difficulty with the authorities in the 1990s but were "rehabilitated" later. A more specifically political novel is Li Jie's The End of the Red Chinese Dynasty (Zhongnanhai zuihou de douzheng 中南海最後的鬥爭,1999), and another daring depiction of a socially engineered authoritarian dystopia is Sheng Keyi's Death Fugue (Siwang fuge 死亡賦格, 2013). Neither has been allowed to be published in mainland China in book form yet. For these four authors, writing in various styles of social satire, political thriller, or dystopian fiction is part of their writer's vocation. They remain primarily either writers or writer-scholars. ${ }^{(9)}$ Venturing into writing on political topics is exceptional in their writing career.

For Wang Lixiong and Chan Koonchung, to a certain extent, venturing into literature is only part of their public activities. Because of the political aspects of their work, Wang's Yellow Peril and Chan's The Fat Years have been grouped together with Li Jie's political thriller, mentioned above, in discus-

4. Henry Y. H. Zhao, "A Fearful Symmetry:The Novel of the Future in Twentieth-Century China," Bulletin of SOAS, Vol. 66, 2003, pp. 456-471.

5. Ibid., p. 470.

6. Bao-mi (Wang Lixiong), Huang Huo (Yellow Peril), Hong Kong, Canada Mirror Books, 1991. Wang Lixiong made revisions later. A noticeable change was to replace the USSR with Russia. See in English, Wang Lixiong, China Tidal Wave, translated by Anton Platero, Kent (UK), Global Oriental, 2008. Hereafter it is referred to as Yellow Peril, unless otherwise noted.

7. Chan Koonchung, Shengshi: Zhongguo 2013 (Prosperity: China in 2013), Hong Kong, Niujin daxue chubanshe, 2009. In English, The Fat Years, translated by Michael S. Duke, with a Preface by Julia Lovell, London, Doubleday, 2011. Chan's name in pinyin is Chen Guanzhong. Hereafter this novel is referred to as The Fat Years.

8. Wang Shuo's novel was initially serialised in three issues of the Nanjing-based bimonthly Zhongshan in late 1989. It was published in book form a few years later. Mo Yan's novel was published in Taiwan in 1992 and in the mainland in 1993. Both were translated into English by Howard Goldblatt and published, in Wang Shuo's case, in London by No Exit Press in 2000; and in Mo Yan's, in New York by Arcade Publishing in 2000.

9. Li Jie, Zhongnanhai zuihou de douzheng (The End of the Red Chinese Dynasty), Hong Kong, Canada Mirror Books, 1999 (in Chinese only). Li was already a noted literary scholar in the 1980s. He is now a New York-based writer-scholar with novels and literary criticism published inside the mainland. Sheng Keyi, Siwang fuge (Death Fugue), Taipei, INK Publishing, 2013. The title is a tribute to Paul Celan's poetry. It has not been authorised for publication in book form inside the mainland. 
sions of the similarities among these writers' imagination of China's political future. ${ }^{(10)}$ However, reading Wang and Chan for their political interpretation alone may miss their broader concerns. For example, both of them developed strong environmental awareness much earlier than most of their contemporaries. In Yellow Peril, Wang presents environmental issues prominently, letting his characters argue and experiment based on his strong convictions regarding ecological security. Three years after publishing the novel, Wang became a founding member of Friends of Nature (Ziran zhi you 自然之友), one of mainland China's earliest environmental groups (he was forced to resign from the group under government pressure in 2001). Likewise, Chan founded the Green Power group in Hong Kong and was once a member of Greenpeace's International Board of Directors. Their deliberate insistence on intellectual independence is also reflected in their shared concern with the situation in Tibet. Wang has published books on Tibet and its political fate, while Chan's second novel, published in 2013, has a Tibetan boy as its protagonist. ${ }^{(11)}$ Both writers are highly critical of Beijing's Tibet policy, considering it detrimental to Tibet's people, culture, and natural environment.

But the similarity between the two authors may stop here. Yellow Peril was published almost two decades before The Fat Years came out. During this period, China's socio-political landscape in the global context transformed dramatically alongside, or because of, the country's rapid economic growth. I shall now turn to Wang Lixiong's Yellow Peril in the next section, with Chan Koonchung's The Fat Years discussed after that.

\section{Yellow Peril: Heroic disaster and hope in primitive conditions}

Wang Lixiong was born in Changchun in China's north-eastern jilin Province in 1953. He grew up in the large compound of China's first automaker, which was built with Soviet aide. Wang's father was trained in Moscow in the 1950s and later appointed a top leader of the company. ${ }^{(12)}$ Wang Lixiong attended a boarding school for children of Party cadres. When the Cultural Revolution broke out in 1966, he travelled throughout China during the "great link-up" of the initial, chaotic months, proudly taking part in "revolutionary" debates and actions. When his parents were detained and his father died under political persecution in 1968, Wang was left to fend for the survival of his younger brother and himself. The experience gave him a strong tendency toward independence. Moreover, the majority of his cohort consisted of youngsters who "thought of themselves as a future Napoleon or Lenin, or at least a future prime minister." To prepare themselves for the future, he recalls later, they "devoured whatever books seemed important and debated day and night over issues concerning world revolution, international politics, and future wars." (13) In addition, they were enthusiasts of classical music and literature, reading Pushkin, Tolstoy, and Victor Hugo and writing their own poetry. Four years in the countryside as a sentdown youth became a window for him to better understand "China." Answering the century-old question "Where should China go?" became a calling that helped him survive the ugliness of injustice, betrayal, violence, and human evil in the decade-long political upheaval. (14)

After studying automobile design in college, Wang returned to the same auto-making conglomerate where his father had worked and died. The idealistic spirit of his youth found new channels in the late seventies when the Reform Era came. He began fiction writing and volunteered to be transferred to another automotive base in central China. There he started writing down his political plan of a gradational democratisation of the electoral system. He quit his job to become an independent writer in 1980. Four years later, he spent two months traversing 1,200 kilometres of the uppermost stretch of the Yellow River in the Tibetan regions of Qinghai and Gansu provinces. A diary of the adventure recorded some crucial thoughts drifting through his mind, especially about the meaning of human life and society, about human beings and nature, and about various cultural traditions with different ethnic origins. These ideas, together with his electoral plan, continued to inform his later writing and activism, including his novels, his environmentalism, and his interest in Tibet and other ethnic regions. ${ }^{(15)}$

Wang Lixiong wrote largely literary works in the 1980s. He was recognised with literary prizes and by becoming a member of the Chinese Writers' Association. Things changed for him decisively in the 1990s (or perhaps even in the late 1980s). After publishing Yellow Peril anonymously abroad, he stopped writing fiction. A sense of urgency against upcoming crisis informed this novel and his subsequent endeavours. ${ }^{(16)} \mathrm{He}$ devoted his energies to intellectually-guided action and analysis, focusing not only on creating a new electoral system, but also on environmentalism, as he joined in founding Friends of Nature. His attention soon shifted to ethnic issues, especially Tibet and the Uyghurs in Xinjiang. ${ }^{(17)}$ It was not until two decades after Yellow Peril's publication that he returned to fiction once again, announcing in May 2013 that he had spent two years writing and had now completed the first draft of a political fantasy, Reincarnation (Zhuanshi 轉世). ${ }^{(18)}$

In addition to the above summary of his life experience, two striking features accompanied Wang Lixiong's intellectual trajectory since the late 1970s. The first is a lasting obsession with his electoral plan for "gradational democracy" (dijin minzhu 遞進民主; zhuji dixuan zhi 逐級彪選制), which he once self-mockingly compared to some people's obsession with perpetual motion machinery. ${ }^{(19)}$ The other, related to this metaphor, is a deeply rooted fascination with technology. Over the course of more than ten years, he established his own websites, each with his electoral proposal as a central

10. Guo Wu, "Imagined Futures in Chinese Novels at the Turn of the 21st Century," ASIANetwork Exchange, Vol. 20, No. 1, 2012, pp. 47-55.

11. In English translation, for example, Wang Lixiong and Tsering Shakya, The Struggle for Tibet, London, Verso, 2009; Tsering Woeser and Wang Lixiong, Voice from Tibet, Hong Kong, Hong Kong University Press, 2013; and Chan Koonchung, The Unbearable Dreamworld of Champa the Driver, London, Doubleday, 2014.

12. Rémi Quesnel, "Wang Lixiong, an Atypical Intellectual," China Perspectives, No. 50, 2003, pp. 57 65.

13. Wang Lixiong, "Wo cong 'wenhua da geming' dedao le shenme" (What I gained from the "Cultural Revolution"), in Wang Lixiong, Ziyou ren xinlu (A Free Man's Searching Path), Beijing, Zhongguo dianying chubanshe, 1999, pp. 10-15.

14. Ibid.

15. Rémi Quesnel, "Wang Lixiong, an Atypical Intellectual," art. cit:; Wang Lixiong, Ziyou ren xinlu (A Free Man's Searching Path), op. cit., pp. 16, 34, 60; pp. 60-157.

16. Wang Lixiong, Ziyou ren xinlu (A Free Man's Searching Path), op. cit., p. 238; and "Preface to the English Edition," China Tidal Wave, op. cit., p. v.

17. Rémi Quesnel, "Wang Lixiong, an Atypical Intellectual," art. cit. Quesnel's article devotes half of its space to a close reading of Wang Lixiong's first writings on Xinjiang and gives only a brief summary of Yellow Peril.

18. A "Preface" announcing the online serialisation and a "Table of Contents" appeared on 1 May 2013. Instalments were uploaded at www.wanglixiong.com and www.woeser.middle-way.net, but with no new material since the end of June 2014, and his website was closed down in late summer 2014.

19. Wang Lixiong, Ziyou ren xinlu (A Free Man's Searching Path), op. cit., p. 237. Wang published a short story in the Democracy Wall journal Jintian (Today Magazine) in 1979, entitled "Yongdongji huanzhe" (Obsessed with perpetual motion machinery) that is collected in Wang Lixiong, Ziyou ren xinlu (A Free Man's Searching Path), op. cit., pp. 34-59. Quesnel and others have translated Wang's electoral proposal differently. I am using HenryY. H. Zhao's translation of Wang's electoral design in this article, since I believe Zhao has best rendered the original intension of Wang's proposal. 
theme. On his latest site, entitled "Ethnic Dialogue and New Media" (Zuqun duihua yu xin meiti 族群對話與新媒體), he initiated an online dialogue between Chinese netizens and the Dalai Lama, whom he has met several times while travelling outside of China. Of interest to our discussion is the subtitle of the website: "On the Internet, [Let's] Transform Utopia into Reality (Zai hulianwang shang, ba wutuobang biancheng you-tuo-bang 在互聯網上, 把烏托邦變成有托邦), and the prominent positioning of his electoral proposal. (20) The confidence in these words seems contradictory to his expressed pessimism about China's future, but is very much in line with his long-term thinking.

It is on this website that Wang Lixiong began serialising his new novel, Reincarnation, in May 2013. However, the uploading was slow and stopped in August 2014. (21) If the novel is going to be about 500,000 characters in length, as Wang announced in his "Preface (Qianyan 前言)" to Reincarnation, there was only about one-tenth available online by mid-2014. It is therefore impossible to give a proper reading of this new novel. However, as Wang makes reference to Yellow Peril in relation to all the main characters, who appear in both novels but engage in different actions and have different fates in two very different settings, the existing parts of Reincarnation, including the "Preface," are helpful to our analysis of Yellow Peril.

The bedrock, so to speak, of Wang Lixiong's Yellow Peril is the challenge that population explosion poses to the limited resources our earth is able to provide, a hot topic among young intellectuals of the 1980s. ${ }^{(22)}$ Launching the Reform Era was a step into untested water accompanied by excitement but also a sense of urgency. Prophesying immanent crises was a common intellectual exercise in those years. Translated futurist works such as Limits to Growth, the 1972 report by the Club of Rome, published in 1984 among the earliest titles in the influential Advancing to the Future book series (Zouxiang weilai congshu 走向未來叢書), were extremely popular. From this perspective, Wang Lixiong's Yellow Peril can almost be seen as a graphic illustration of a doomsday prediction. As the story unfolds, we see that a root cause of social conflict is the fight for limited resources. The absolute size of China's population means that a crisis of this scale is unfathomable to the world (pp. 457-64). When the food supply becomes scarce, it is the end of human civilisation. In the last part of the novel, the reader reads page after page of sickening depictions of human beings reduced to greedy beasts under the pressure to survive. The only things they still care about are consumption and reproduction (e.g. pp. 626-40). "The Globe was revolving backwards, back to the bleak desolation of the Cretaceous Period." (China Tidal Wave, p. 524)

Critics have summarised the novel in various ways, usually identifying Shi Ge as the protagonist, who, with a modest demeanour and coming from a think-tank background affiliated with the central government, becomes Premier after the Chinese military and other top politicians are crushed in an escalating international intervention. ${ }^{(23)}$ Shi Ge indeed plays a central role in the novel's construction. His secret project to push nearly a billion Chinese refugees across oceans and borders onto other continents contributes directly to the full-fledged nuclear war between the United States and the USSR. Meanwhile, a subplot involving Shi $\mathrm{Ge}$ in a love triangle runs throughout the novel. The woman scientist Chen Pan ultimately leaves the ambitious environmentalist Ouyang Zhonghua for Shi Ge in a contest between two proposals to save mankind for future good, symbolising a central theme of the novel.

However, to single out Shi Ge could be misleading in reading the novel. The main body of the novel, the first 400 or so pages out of 643 in the Chi- nese original, relates the intense dramas leading to the international intervention and has the love-triangle trio mainly on the waiting bench. The central hero of this part is Wang Feng, a "red princeling" in his forties who is strategically positioned in the central military leadership. He is responsible for making almost all the major decisions that lead to the final disaster, from assassinating the Party Secretary-general and secretly building a nuclear submarine, to launching a south-north civil war and firing the initial nuclear missile at Taipei, setting off a chain-reaction that clears the stage for the novel's final part. Accompanying this line is Li Keming, an experienced local police officer whose professional excellence and heroic spirit bring him into several critical moments, fighting first against Wang Feng's conspiracies and then against Taiwanese revenge plots, and finally against a Russian plan to poison hundreds of millions of Chinese refugees, before he is killed by the combination of a Japanese trap and Russian bullets. Undisturbed by Shi Ge's concern about limited resource and Ouyang Zhonghua's dream of a green future, episodes in this storyline are filled with coldblooded violence and calculating political intrigue and are written in a thriller style, often with cinematic pace and effect. It is also in the first twothirds of the novel that the author captures an array of characters among the PRC political and military elite. The pointed sketches are often rich in insightful characterisation, presenting to readers of PRC background with a convincing dramatisation from an insider's view. This, I believe, constitutes one of the main appeals of Yellow Peril.

Although Wang Feng almost singlehandedly pulls China and the world into massive catastrophe, and although Ouyang Zhonghua fails his own high-minded ideals and ultimately behaves no less barbarously than those men-turned-beasts, it is important to recognise that neither is presented as a caricature "villain" in the novel. More than 20 years later, in his "Preface" to Reincarnation, Wang Lixiong says:

Characters I depict are usually not those spineless persons being carried around by fate. They not only struggle to control their own fate, but try to affect the fate of their society as well. I prefer to portray characters with such personalities. I see in them the hope of guiding China forward and avoiding [the kind of future presented in] Yellow Peril. People of this sort are unusual and few in number. The majority of people in the world live only for themselves. It is this tiny minority alone who live to change history. And our present age falls at the exact juncture when history is due for a major reshuffle. (24)

Close reading indicates that, besides Shi Ge and Chen Pan, the other main characters all belong to this tiny minority, especially Wang Feng, who is one

20. At www.wanglixiong.com (accessed on 30 July 2014), his electoral design was positioned at the top by a link marked out with the words "Minzhu 2.0: Cong shuliang minzhu dao shiliang minzhu" (Democracy 2.0: From numerical democracy to vector democracy). This website is no longer accessible. The online event with the Dalai Lama was made into a documentary, Dialogue, by filmmaker Wang Wo, which can be viewed on the website run by Wang's wife, Woeser, at www.woeser.middle-way.net (accessed on 23 November 2014).

21. Although Wang's website is no longer accessible, previous postings of this novel could still be viewed on Woeser's website on 23 November 2014.

22. All page references given in parentheses in this section are from Wang Lixiong, Yellow Peril, op. cit., unless indicated as coming from Wang Lixiong, China Tidal Wave, op. cit.

23. Henry Y. H. Zhao, "A Fearful Symmetry," art. cit., p. 461; Rémi Quesnel, "Wang Lixiong, An Atypical Intellectual," art. cit., online paragraph 6; and Wu, "Imagined Futures in Chinese Novels at the Turn of the 21 st Century," art. cit., p. 48.

24. The Chinese text was originally posted on Wang Lixiong's website on 1 May 2013. It was still accessible in late November 2014 at www.woerser.middle-way.net, post dated 22 May 2013. The translation is mine. 
of the most positive portrayals of a "red princeling" in contemporary Chinese literature. Handsome, ambitious, fascinated with technology, strictly precise, and always composed, Wang Feng is neither corrupt nor blindly egoistical, but is mainly motivated by honour and duty. Even Shi Ge recognises Wang Feng's noble spirit (p. 586), which shines in the direst circumstance and terrifies a lowly vagabond (pp. 602-3). In a fleeting moment of emotion, he sighs that he has lost his youthful ideal of becoming China's Napoleon, but this is the moment when China will not survive without one and he has to respond to his calling (p. 391). Honour and duty, in the form of historical responsibility, have nothing to do with the Party and its traditional ideology but rather with the nation and the army he is obliged to serve with absolute loyalty. Here is how he handles the power transfer to the USA and USSR after China comes under nuclear attack by the two superpowers:

Wang Feng looked very distinguished, tall and straight, the sun on him, as he came down the steps with great dignity. The two ambassadors stood side by side with smiles that did not even crease their faces, and stretched out their hands. Wang Feng looked closely at the two faces, slowly stretched out his hand and said,

"I don't see your Presidents, only their representatives..." Then he suddenly slapped their faces, so hard that they fell down on the red carpet, bleeding from nose and mouth.

The band continued to play the Chinese national anthem and the flag of China with its five stars fluttered in the wind. All the soldiers continued to stand to attention and salute. The two men made an effort to stand up and regain their dignity, but they were dizzy and could not keep their feet.

Wang Feng looked at them until the last strains of the national anthem died away. An orderly handed him a white towel; he wiped his hands, as if after a banquet, and threw it down at the feet of the two ambassadors. Then he saluted all the officers and under their astonished and admiring eyes, went back into the headquarters.

(China Tidal Wave, p. 352).

Comparatively, Ouyang Zhonghua is also "born to be extraordinarily great man" (p. 613) but with greater intellectual orientation. He preaches an aesthetic philosophy of spiritually fulfilled human life in an environmentalfriendly green lifestyle. His internationally acclaimed book is entitled The Spiritual Man (Jingshen ren 精神人; p. 42; pp. 74-78), a term that Wang Lixiong himself pondered while drifting down the Yellow River in 1984. Ouyang's personal background also shares some features with Wang Lixiong's own. However, for Ouyang, the only way to realise his grand ideal on earth is to rewire human civilisation from zero. To prepare for this, he obtains financial support from Shi Ge to transform several national parks in obscure locations into survival bases. These enable him to establish a powerful network in time of crisis, with which he manages to save as many scientists and artists as possible from a "nuclear winter" for purposes of future reconstruction. He is obliged to block the poor masses from entering his base, often through the resolute use of violence. As a result, he also has to deal with the "wrong" impression of "might is right" within his militia team, which soon turns against him, and he himself has to kill in order to preserve his base and himself. This causes him painful self-doubt in the end.

As noted earlier, the novel's structural setting assigns different narrative functions to its heroes. The first, larger portion of the story inhabited by Wang Feng sees scarcity of resources threatening China and her people, but that problem alone could not have pulled the country into crisis. This is a primarily world of coincidence and personality clash. It is along this line that Wang Lixiong issues his prediction of China falling into a downward spiral and his critique of the modern world with its unbridled consumption and dangerous curiosity (e.g., towards nuclear weapons).

Ouyang Zhonghua, on the other hand, encounters his ultimate challenge in the second, shorter portion of the novel at a stage at which his green proposal, brought to ruin by the internal contradictions mentioned above, is unfavourably contrasted with Shi Ge's gradational electoral system (pp. 423-25), Wang Lixiong's pet project in the novel. Similarly unfavourably contrasted is American democracy, regarded as the least efficient and driven by mindless and volatile mass reaction that is unable to handle crisis on a global scale (pp. 571-77). For Wang Lixiong, as for H. G. Wells, the key condition for a contest of utopian visions is a global catastrophe. ${ }^{(25)}$ The flood of Chinese refugees, the Yellow Peril, brings the new possibility of a global society. The modern state, national borders, political parties, armies, banks, capital, market, even currency for the exchange of goods, have all disappeared. People have learned to restrain their needs and to work collectively. "Although people were still struggling for survival from starvation and death, they came closer than at any other time to the kinds of society that mankind has always dreamed of" (China Tidal Wave, p. 511). A catastrophe becomes a catalyst for a primitive Utopia for humankind on Earth.

It is beyond the scope of this paper to fully assess Wang Lixiong's sociopolitical utopian proposal. Here are a few quick notes on his gradational election of a centralised power-sharing system. First, despite Wang's repeated emphasis on bottom-up elections to guarantee voter will, the system's graduated levels of expertise ensure socio-political hierarchy without considering the impact on social equality. Second, even when a disastrous situation reduces people to focusing on basic needs and so provides the best conditions to institute the system, it has to be "installed" or instilled top-down into the minds of the masses by an existing elite. In this regard, there is no real difference between Wang Feng, Ouyang Zhonghua, and Shi Ge. They are there to demonstrate that solutions to our world's problems have to wait for virtuous elites to take action or, as in Shi Ge's case, to have pity on the masses. Similarly, these elites share another feature in implementing their very different institutional designs, which is the use of ends to justify means, even in the case of the most sympathetic Shi Ge. To safeguard the passage of Chinese refugees going westward via Central Asia, Shi Ge orders the military to clear Xinjiang's Muslim population in a ruthless operation. Intriguingly, the incident is referred to in just two or three sentences (p. 465, 476), with no detailed depictions as in cases involving other heroes. With his more recent work on the Uyghur population in Xinjiang, Wang Lixiong may have changed his view about how Shi Ge should solve the problem.

Last but not least, Yellow Peril was written when the CCP regime seemed to be at its most precarious point in the PRC's history. Despite quelling the 1989 Tiananmen protests to hold onto power, for almost three years until Deng Xiaoping's Southern Tour calling for greater reform in early 1992, the Party appeared to be losing ground except for empirical reasons. That the Party had given up any genuine ideological position can be seen in Deng's famous directive of "no more argument over Capital S (for socialism) versus Capital C (for capitalism)." Perhaps because of this, Wang Lixiong does not

25. Gregory Claeys, "The Origins of Dystopia:Wells, Huxley and Orwell," in Gregory Claeys (ed.), The Cambridge Companion to Utopian Literature, Cambridge, UK, Cambridge University Press, 2010, pp. 107-131, esp. p. 114. 
take issue with China's institutional setting or the Party's claims to legitimacy. As seen earlier, he mainly questions modern democracy in the West and green philosophy. Inevitably, these Western positions are presented only in scattered sketches that leave Wang a weak interlocutor intellectually. It is not an effective way to play up his own proposal, either.

That said, we must recognise that Wang Lixiong was, and still is, firmly against strong-man dictatorship or authoritarian Party rule. In the novel, Wang Feng and Ouyang Zhonghua meet terrible ends as they are driven by an excessive desire for political power. In contrast, Chen Pan turns to Shi Ge precisely because of his qualities of being normal, humane, modest, and understanding (p. 613), qualities that Wang Lixiong wants to inject into his political design. He is determined to be on the side of true democracy for ordinary people. The most interesting aspect of this novel, written in Communist China in 1991, is that the contest between different models for humanity's future is not based on "inevitable outcomes" of predestined historical paths as argued by the Communist camp in the Cold War years. National dignity is confirmed, but it alone is considered insufficient to provide a future blueprint for humanity's common welfare; nor is it the noblest cause for people's wholehearted devotion. In this respect, Yellow Peril remains one of the most important works coming from post-socialist China.

\section{The Fat Years: Good Hell versus counterfeit Paradise}

Generally speaking, the narrative dynamic of Yellow Peril is anchored on clashes between individuals or political forces, in curious contrast to the genre tradition of utopian/dystopian literature, which is typically based on a clash between conflicting ideas. ${ }^{26)}$ This is especially the case in dystopian classics such as Aldous Huxley's Brave New World (1932), George Orwell's Nineteen Eighty-four (1949), and Margaret Atwood's The Handmaid's Tale (1986). The dystopian world in these works is typically organised according to a dominating ideological discourse that controls people's way of life with omnipresent, absolute authority. The few individuals who are not fully inculcated are isolated oddities and therefore the key narrative device for questioning the dominant social order. The dystopian genre, in such cases, pushes the "logic" of certain mainstream ideas in our daily reality to the extreme to create a presumably non-realistic situation in which all social life is organised strictly according to the logic of the ideas. In so doing, these literary works are able to expose the absurdity of, and challenge the blind spots potentially hidden in, the "logic" that already exists in our life. This is basically the case with Chan Koonchung's The Fat Years, although with key variations.

Chan Koonchung is only one year older than Wang Lixiong, but they have had very different life experiences. Born in Shanghai and growing up in Hong Kong, Chan studied sociology at Hong Kong University, went on to Boston University to study media, and returned to Hong Kong to work as a journalist in the mid seventies. The post-war baby boomers were coming of age in a kind of political disorientation, unable to identify, as their parents did, with either the CCP regime in Beijing or the KMT in Taipei. The British colonial authority in Hong Kong was trying to pacify the social unrest of the previous decade by emphasising services to local communities, but without any substantial effort to contribute to a Hong Kong identity. Chan and a few friends set up a new journal called (literally) Special Supplement (Haowai 號外) to give a voice to the city they had grown up in and to their own generation. Inspired by the counterculture movement of the sixties and seventies in the West, which Chan had witnessed personally, they explicitly modelled the journal on New York City's Village Voice. Haowai distinguished itself instantly by offering lengthy investigative reports on social problems in the city, "camp"-style reviews, in-depth interviews, experimental literary works, and much more. Their poorly managed initial issues drew interest instantly, and investment soon followed. The journal repackaged itself, changing its English name from The Tabloid to City Magazine. It has since become one of the city's cultural legends. ${ }^{(27)}$

Chan was City Magazine's first Chief Editor and publisher, playing a crucial role in determining its shape and style. However, he was not known as a writer except for a single short story written in 1978. It would be another 20 years - reminiscent of Wang Lixiong's two-decade gap between Yellow Peril and Reincarnation - before Chan wrote his second story about Hong Kong in 1998. By this time, the magazine had changed hands several times, and Chan had moved away from the city, spending a few years on the mainland in the early 1990s and then six years in Taiwan working for a cable television station. He has been based in Beijing since 2000. In his own words, political upheavals in the mainland and Taiwan in the post-war decades provided him with new perspectives on Hong Kong, reflected in the title to his 1998 novella, "Nothing Has Happened" (Shenme dou meiyou fasheng 什 麼都没有發生). Under British rule, as a character in the novella comments, "We are all conscripts of international capital in Hong Kong" (Women doushi guoji ziben zai Xianggang de guyongbing 我們都是國際資本在香港 的雇傭兵) and nothing more. For his generation in Hong Kong, there was none of the revolution, heroism, or sublime vision that has informed Wang Lixiong's literature.

Living in Beijing as an outsider, Chan has produced several books on Hong Kong's socio-cultural reality and its political future, but not on mainland issues. In interviews he explained that he had been mingling with leading cultural figures in Beijing and Taipei before the new century, and in addition to his old acquaintances, he got to know many leading intellectual dissidents as well. Beijing's cultural circles were bubbling with various issues at any given moment, and an outsider had difficulty grasping enough to write meaningful commentaries. Then events in 2008 made the overall picture crystallised for him. It was still in mosaic-like form, so fiction was the best choice to capture what was in his mind. He wrote The Fat Years as a result. (28)

The novel presents a slice of an imagined reality set in China in 2013, three or four years away from its original publishing date. ${ }^{(29)}$ The timing makes it close to the present day, hastening the intended effect of being familiar and absurd at the same time. It brings a notable difference from

26. Fátima Vieira, "The Concept of Utopia," in Gregory Claeys (ed.), The Cambridge Companion to Utopian Literature, op. cit., pp. 3-27.

27. Special weekend stories on the City Magazine, The House News, 21 July 2013, www.thehousenews.com (accessed on 4 July 2014) and "Chen Guanzhong tan Luo Ming: Zhongguo zuojia de xiangxiang buru xianshi huangdan" (Chan Koonchung on The Unbearable Dreamworld of Champa the Driver. Chinese writers' imagination is not as absurd as reality), The New York Times (Chinese), 4 March 2013, http://cn.nytimes.com/culture/20130304/cc04chenguanzhong (accessed on 4 July 2014). The House News website was closed down unexpectedly on 26 July 2014. Its online content was no longer accessible at the time that this paper was written. Hong Kong netizens, convinced that the closure was due to Beijing's pressure, launched a campaign to rescue its online content. See www.bbc.co.uk/zhongwen/simp/china/2014/07/140727_hongkong_housenews_foldup.shtml (accessed on 31 July 2014). There was no further news on the content as of November 2014.

28. "Liang Wendao: Shengshi lengyan - fangtan Chen Guanzhong" (Leung Man-tao: Coolly observing prosperity - Interview with Chan Koonchung), Dushu hao (Life and Reading Culture), No. 27, December 2009, www.books4you.com.hk/27/pages/page8.html (accessed on 31 July 2014).

29. All page references given in parentheses in this section are from the English version, Chan Koonchung, The Fat Years, op. cit. 
classical dystopian works as well. With numerous references to contemporary events (e.g., the 2008 Beijing Olympics), the imagined state of affairs is not as neatly organised as in, say, Orwell's Nineteen Eighty-four. In the officially designated "China's Colden Age of Ascendency," the story goes, almost everyone is experiencing "a small-small form of happiness," dubbed "High-Lite-Lite" (pp. 140-41), highlighted in English on the promotional girdle of the Chinese version. Missing in this setting are two factors that readers familiar with Huxley's Brave New World might be expecting: on the one hand a clearly spelt out, dominating ideology - that is, until to the very end - and on the other a highly disciplined hierarchy issuing orders to members of society with threats of swift punishment.

Rule by fear, the archetypal evil against human liberation in typical dystopian literature, is not present in its daily operational form in The Fat Years, but rather in a bolt of lightning that precedes the novel's present time by two years. ${ }^{(30)}$ Furthermore, fear is not directed at power exercised against individual citizens but rather at potential social anarchy. The ruling power, in turn, becomes the most desired saviour rescuing the masses from fearful chaos. How this is possible becomes the main suspense of the narrative, and the full answer does not reveal itself until late in the Epilogue (pp. 23852). The point is, when the ruling power struck two years ago, there were many victims of its very swift and severe punishment. They were completely forgotten by the public. Equally important is that the generally complacent atmosphere prohibits individuals from raising unpleasant questions. These two issues are threaded through the novel, leading to the final revelation, which, as we shall see, does not provide solutions but poses challenging questions for our time.

The first half of the novel is narrated by several characters in the first-person voice, mostly by a Taiwanese writer, Old Chen, who happens to also have some roots in Hong Kong and now resides in Beijing (pp. 45-52), perhaps a mirror image of the author himself. The other half is in third-person voice, but again largely following Old Chen's activities, making him the centre of the narrative structure. Old Chen's narrative function is tri-fold. Firstly, he is the main mediator in other people's troubling obsession with the absurdity of their living environment - specifically, two of Chen's old acquaintances whom he has not seen for a long time. Secondly, his voice in Part One and the third-person voice in Part Two provide, through various episode details, a panoramic socioscape of the Chinese "Colden Age." Thirdly, without getting emotionally involved in the quandaries troubling his two friends while neither of them has elaborated on the questions theoretically, Old Chen's ruminations appear to be notes on the thinking of his friends, but in fact offer critical commentary on the situation and counter claims that tacitly support the existing order. Most importantly, in all of these functions, particularly the second, the narrative maintains a laid-back style. Even when discussing critical ideas, Old Chen sounds uncertain and reluctant to pursue the issue at hand. In short, his position as protagonist never overshadows the idealistic spirit of his two friends, who are the real hero and heroine of the novel.

The two friends are Fang Caodi, a China-born Chinese-American returning to China to live, and Little Xi, a Beijing native who eventually embraces Old Chen in a romantic relationship. The novel opens with Fang Caodi's observation: "One whole month is missing" (p. 27). It is the month when the lightning bolt struck, during which Fang himself barely escaped while witnessing chaotic scenes. It was immediately after that month that the government announced with great fanfare the arrival of "China's Colden Age of Ascendency." To erase people's memory of terror, the authorities have removed all possible records of that month. Fang has scavenged piles of bits of paper as evidence, but no one seems to believe him or even cares to listen to him. Fang's crusade is against collective amnesia combined with government censorship. Little $\mathrm{Xi}$ is a law school product, but she resigned from her enviable job as a judge 30 years ago in the 1983 "strike hard" (yan da 嚴打) campaign that dealt out swift punishment against alleged social crimes. She simply could not bring herself to aid the politically motivated executions of people without fair trial. However, she does not remember the missing month two years earlier, since she was in a mental hospital. When released, she is shocked to find that no one wants to look at history or criticise the authorities any longer. Her question is why we should give up independent thinking. She, too, has "[thrown] herself into solitary combat" (p. 222). Her battle is against conformism and compliance.

The pair's crusading spirit is in contrast but also complimentary to Old Chen's semi-detached air in the narrative. Old Chen and Fang Caodi, with their non-PRC identities, are outsiders not fully assimilated into the local order. Little Xi, meanwhile, is a voluntary internal exile further marginalised by the fact that plainclothes police are constantly following her due to her postings on the Internet through frequently changing accounts. Their odd position vis-à-vis society at large sharpens the novel's dystopian edge. Meanwhile, the spirit exhibited by Fang Caodi and Little Xi is not sceptical ambiguity but determined defiance. These are not ambitious heroes destined to change the course of history, like those in Yellow Peril. Instead, they are standing alone and "radically idealistic" (pp. 221-22). At the beginning of the Epilogue, when the two finally meet, their case is explained in a historical account:

Hundreds of millions of Chinese lived through an age that witnessed a storm of idealism and were baptised in that flood of idealism. Even though later on their ideals turned to nightmares and disillusionment, and an entire generation of people lost their ideals, still they didn't abandon idealism.

Fang Caodi and Little Xi had grown up in that turbulent era. (p. 214)

More importantly, Little Xi has learned to argue anonymously but tirelessly on the Internet, with clarity and lucidity, about steadfastly looking at historical truth and fighting for justice (pp. 222-23).

We are not told the contents of her postings, but there is a curious inversion of some more familiar dystopian settings: the marginalised figure is holding up clarified ideas while the dominating order is extremely vague and evasive in its political discourse. The light-hearted vagueness is presented in the panoramic portrayal of a society permeated by ecstasy over China's rise, as Old Chen mingles with the cultural elite, urban socialites, and successful business people with political connections who dominate mainstream discourse. It lends satire to the novel with numerous barely concealed references to social phenomena in contemporary China. Supplementing this is a rural-based episode in the second part. Even there, straightjacket-style top-down thought control is replaced by more sophisticated manoeuvres. Parallel to college students informing on liberal-minded professors in the city (pp. 87-88), pastors purposely lead religious prayers that steer followers' minds away from demands for social justice (p. 202; pp. 206-9).

30. In the original Chinese version, the number of years between the lightning bolt and the novel's present time is not specified, although it cannot be more than the four years from 2009 to 2013. The English version, published in 2011, indicates it to be two years specifically. 
The hypocrisy of society is best captured in a proposal of ten policy suggestions:

a one party democratic dictatorship;

the rule of law with stability as the most important element;

an authoritarian government that governs for the people;

a state-controlled market economy;

fair competition guaranteed by state-owned enterprises;

scientific development with unique Chinese characteristics;

a self-centered harmonious foreign policy;

a multi-ethnic republic ruled by one sovereign ethnic group of Han

Chinese;

post-Westernism and post-universalism as the nation's chief world views;

the restoration of Chinese national culture as the world's unrivalled leader. (pp. 146-47)

Proposed by a founding editor of China's leading intellectual publication, the Reading Journal (Dushu 讀書), these items have all become "firmly established principles," and the editor has been officially recognised for his contribution to China's New Era of Prosperity (pp. 146-47). With twists concerning China's reality, these statements echo George Orwell's famous line in Animal Farm: "All animals are equal, but some animals are more equal than others." The difference is that The Fat Years is not concerned with demonstrating how such absurd principles are put into social practice. Its focus is on the solitary battles fought by our relatively isolated protagonists to retain the possibility of serious intellectual engagement in public life, including, but not limited to, being truthful about collective history.

In fact, by threading battles against collective amnesia and conformist compliance throughout the novel, the author has apparently omitted or downplayed some very dark aspects of Chinese society today. ${ }^{(31)}$ The only violent incident directly depicted is committed against a peasant migrant worker in the city by a group of ultra-nationalist college students. Every time Little Xi appears in Beijing, we are told in some way that she has been followed. But the security agents never come to the fore. The emphasis is always somewhere else, drawing our attention away from state-sanctioned violence in people's daily lives. Even when the story shifts to the countryside, where peasants are agitating over a land seizure, the incident is relayed through layers of remove, and the raw emotion of the abused is not seen. This is not a political novel of exposure. It is about valuing independent thinking and ideas.

The most obvious clash of ideas occurs in the Epilogue, which gives $\mathrm{He}$ Dongsheng, a high-ranking official, a conspicuous opportunity to make his case on behalf of the regime. He admits that our heroes' suspicion is justified. When China was hit by economic crisis two years earlier, the state deliberately stood by and let society descend into complete anarchy for a whole week, "what Thomas Hobbes called 'the war of all against all'" (p. 250), to pave the way for a three-week long "severe and rapid" crackdown that established the Chinese Leviathan as the sole guarantor of social order. However, He says, it would be cheap sympathy to cry out against the injustice suffered by victims of the campaign. Stability under the state of absolute prestige is but the means and "not the ultimate goal - we need stability in order to accomplish great things" (p. 252). To secure the total success of the whole project, the government immediately announced the arrival of China's Golden Age of Ascendency and at the same time started adding a certain chemical substance to the water supply nationwide, which has induced a universal "high lite-lite" state in most people. Fang Caodi and Little Xi, along with scattered others, are not affected, because they are taking medication for asthma and depression, and because they are intellectually independent and inherently resistant to thought control. Where $\mathrm{He}$ Dongsheng's story shocked the protagonists most is about the missing month. It is the Chinese people themselves who have opted to forget it, providing the best opportunity for the Central Propaganda organs to do their censorship work. Otherwise, He says, "we could not have forced" people to forget (pp. 295-97). This depressing revelation ends the story, but it is not the end of the questions raised by the novel.

According to He Dongsheng, the "great things" to be accomplished by the Leviathan State are primarily five policy measures, all from a central-left position to the extent that at one point, "Little Xi and Fang Caodi nodded in agreement" (p. 262). Here the author pushes his "logic" again to leave the government a clean record in running its business after the hard strike, which is far from the corruption-laden Party-state of today's reality. The question becomes two-fold. First, should a government be forgiven for covering up its bloody past so long as it adopts optimal policies for the people? Second, should the public openly scrutinise and debate official decisions when the government has adopted the best possible policies embodying economic social justice? The protagonists and He cannot mend their disagreement over the answers to this socio-ethical dilemma, which is a central issue in the book. In previous chapters, it takes the form of contrasting a good Hell with a counterfeit Paradise. ${ }^{(32)}$

"In a good hell," we are told, "people are aware that they are living in hell and so they want to transform it, but after living for a long time in a fake paradise, people become accustomed to it and they actually believe that they are already in paradise" (p. 161). In John Milton's Paradise Lost, a paradise is understood to be part of what defines the human condition and lends meaning to human existence. The problem with a counterfeit paradise is that it is based on lies and erasure of collective memory. People living there are not really innocent but accommodate oppressive pressures out of fear for their own safety and potential material prosperity. An idealist who insists on seeking truth and preserving memory, Little Xi embodies the strongest conflict with the fake version of paradise on earth that she finds China has become. She fights for social justice that is also directly threatened by the conformist nature of the fake paradise. He Dongsheng's answers, to her understanding, are essentially a developmental logic that unfortunately has become rampant worldwide today. Little Xi seems to lose the battle in her confrontation with $\mathrm{He}$, but the issues lingering in the reader's mind keep her resistance alive as one of the best possible manifestations of true human spirit.

With rich textual references and lengthy discussions by its characters on policy and political and historical issues, The Fat Years appears to keep its central questions one step away from being fully explicated until the very end. Yet, the seemingly pessimistic ending, when the main characters can make personal choices only by leaving the social setting that has excited their public concerns, forces the reader to reflect further on historical mem-

31. Michael Duke, "Translator's Note," in The Fat Years, pp. 300-07, esp. 302, where Duke points out social groups missing from the novel's portrayal.

32. The idea of a "good Hell" comes from Lu Xun, which the novel acknowledges through Old Chen's contemplation, but its connotation changes in the novel from that in Lu Xun's satiric-philosophical essay. The novel shifts the contrast from a "good" versus a "bad" Hell in Lu Xun's writing into a truthful Hell versus a false Paradise. See Michael Duke (trans.), The Fat Years, op. cit. 
ory, the freedom to think independently about public issues, and so forth, against the dominating discourse that values economic issues over everything else.

\section{Conclusion}

In less than half a century, the world has moved from worrying about exhausting Earth's natural resources to universally hailing infinite growth. This period covers China's Reform Era since the late 1970s. The Chinese experience is therefore integral to global concerns, and in its latter manifestation, possibly part of the cause of global problems. These years are important also in terms of the rising technological economy that has been changing our living experience in significant ways. New technologies, or new ideas about future potential, rapidly rushed into Chinese translation once the country re-opened her doors to the outside world in the 1980s.

Wang Lixiong's Yellow Peril and Chan Koonchung's The Fat Years, two imaginative utopian-dystopian novels, respond not only to China's domestic political issues, but also to their worldwide implications. The books are nevertheless distinctly different in style, focus, and theme. We mentioned dramatic scenes in Yellow Peril. In contrast, The Fat Years adopts a subdued tone, even when very dramatic events are occurring, such as the kidnapping episode that leads to the epilogue.

The different styles are directly related to how the two novels incorporate elements of science fiction into their respective narratives. Wang Lixiong's continuing fascination with scientific ideas and new technology provides a key solution in Yellow Peril to the final, primitive utopian collective in the form of an artificially produced potato-like foodstuff invented by the woman scientist Chen Pan. ${ }^{(33)}$ More importantly, the author's fascination is almost tangible when he gives the detailed layout of a nuclear submarine, describes with minute precision an assassin's preparation work, or narrates a large-scale military confrontation in a complex geographical setting. Chan's The Fat Years, on the other hand, sets up suspense through technological manipulation - an officially developed drug being secretly added to the drinking water supply to keep the general populace constantly content - only to dismiss it at the end as making no contribution at all to people's forgetfulness, which is voluntary especially in respect to unpleasant historical events.

Curiously, some basic themes in Yellow Peril are also seen in a number of contemporary science fiction works from China. For one thing, civilisation is extremely fragile in such works if we consider how easy cannibalism comes about as a "natural" consequence when survival becomes the top priority. Related to this is the concept of the constant threat of scarcity of resources. Unlike some recent works in which scarcity of resources becomes a source of international confrontation, in Wang Lixiong's work it remains the root cause of crisis for all humanity. Wang's concern in Yellow Peril is not nationalistic at all. When Chinese refugees bring the gradational election scheme to other parts of the world, it is not presented as China's triumph as the ultimate saviour of mankind, but instead offers mankind a precious opportunity to reflect on the purpose of people living together as a society. ${ }^{(34)}$

Chan Koonchung does not share Wang's anxiety over such themes. His dystopian construction is on the surface much closer to its Western cousins than most contemporary Chinese writers of either dystopian or science fiction. Meanwhile, Chan does not construct his dystopian world as a criticism against humanity's presumptuous usurpation of God's work. Instead, at times The Fat Years pays homage to Lu Xun, modern China's greatest writer, in particular to his idea that the masses and society are all responsible for killing individual independence and suffocating intellectual creativity. It is difficult to say that the thematic difference between Yellow Peril and The Fat Years are due to the authors' different backgrounds - from the mainland, or from outside of it. In both cases, pessimistically speaking, we may have plenty of opportunities to read more nightmarish dystopian stories coming from China as a rising superpower.

IChaohua Wang is an independent scholar, based in Los Angeles, California. (wangc@humnet.ucla.edu).
33. I am grateful to be reminded this point by one of the anonymous reviewers of this paper

34. This is the view of Henry Y. H. Zhao, who implies that Wang Lixiong in this novel demonstrates the usual mindset among Chinese writers of worrying about China. Henry Y. H. Zhao, "A Fearful Symmetry," art. cit., pp. 461-62, 469-471. I disagree with this view. 